\title{
Comparative study of elderly care services among Iran, United States of America, and Sweden
}

\author{
Nasrin Shaarbafchi Zadeh ${ }^{1}$, Faezeh Akbari ${ }^{2}$, Parinaz Khalili Khouzani ${ }^{3}$, Asal Sadat Niaraees Zavare ${ }^{4}$
}

1.Assistant Professor, Health Management and Economics Research Center,Department of Health Services Management, School of Management and Medical Information, Isfahan University of Medical Sciences, Isfahan, Iran. ORCID ID: 00000001-7104-2214

2.Master of Science Student, Health Services Management, Students Research Committee, School of Management and Medical Information, Isfahan University of Medical Sciences, Isfahan, Iran. ORCID ID: 0000-0003-1194-5686

3.Master of Science Student, Health Services Management, Students Research Committee, School of Management and Medical Information, Kerman University of Medical Sciences, Kerman, Iran. ORCID ID: 0000-0001-5920-8680

4.Master of Science Student, Health Services Management, Students Research Committee, School of Management and Medical Information, Isfahan University of Medical Sciences, Isfahan, Iran (Corresponding Author). Postal address: Isfahan, Hezar Jerib Avenue, Isfahan University of Medical Sciences, School of Management and Medical Information. Email: asa17447@gmail.com, Tel: 09217334830. ORCID ID: 0000-0001-7742-9284

\begin{abstract}
Background and Aim: According to statistics, the world is rapidly moving towards aging. The aim of this study was to compare United States of America, Sweden and Iran in regard to population aging status, types of aged care services and types of aged care service providers.
\end{abstract}

Materials and Methods: This study was conducted using a descriptive-comparative approach in 2019. Data were collected by reviewing the texts in the libraries and the websites of the relevant organizations of the selected countries. The references used were in Persian and English languages between 2000 and 2019.

Results: The results showed that Sweden and the United States have faced the population aging phenomenon earlier (than Iran) and have more diverse services in regard to the various aspects of life for old people and also a wider population coverage.

Conclusion: Based on the results of this study, we recommend the use of the experiences of successful countries that have faced the elderly crisis before Iran. Some of the issues that should be considered include: public coverage of social and health insurance for the old people, use of volunteers and private sector capacity, integrated care using an interdisciplinary team, use of modern technologies such as smart alarms and Eldercare Locator Software, needs assessment and capacity building for human resource training, and considering financial and non-financial support for the families which take care of their elderly members.

Keywords: Comparative study, Aged, Health services for the aged, Housing for the Elderly, Retirement

Received: Oct 16, $2019 \quad$ Accepted: May 29, 2019

How to cite the article: Nasrin Shaarbafchi Zadeh, Faezeh Akbari, Parinaz Khalili Khouzani, Asal Sadat Niaraees Zavare. Comparative study of elderly care services among Iran, United States of America, and Sweden. SJKU. 2020;25(5):123-140.

Copyright (C) 2018 the Author (s). Published by Kurdistan University of Medical Sciences. This is an open access article distributed under the terms of the Creative Commons Attribution-Non Commercial License 4.0 (CCBYNC), where it is permissible to download, share, remix, transform, and buildup the work provided it is properly cited. The work cannot be used commercially without permission from the journal 


\title{
مطالعه تطبيقى خدمات مراقبت از سالمندان در ايران، ايالات متحده آمريكا وسوئد
}

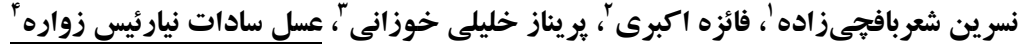

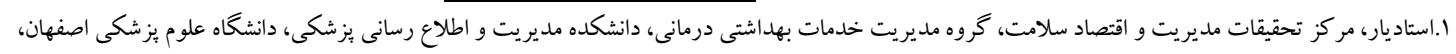

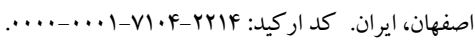

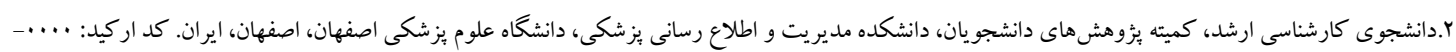 \\ $.0919-1194-\ldots r$

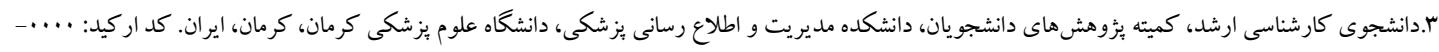 \\ $\Lambda 9 \Lambda \cdot-\Delta Q Y \cdot-\cdots \cdot \mid$ \\ F.ا.دانشجوى كارشناسى ارشد، كميته يزوهشهاى دانشجويان، دانشكده مديريت و اطلاع رسانى يز شكى، دانشكاه علوم يزشكى اصفهان، اصفهان، ايران (نويسنده مسئول)،

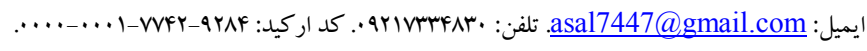

جكيله

زمينه و هدف: بر اساس آمار و ارقام، جهان به سرعت در حـال حركت بـه سـمت سـالمندى جمعيـت اسـت. هـدف ايـن مطالعهـ مقايسهى كشورهاى اير ان، ايالات متحـده آمريكـاو سـوئد از نظـر وضـعيت سـالمندى جمعيـت، انـواع خـدمات سـالمندان و انواع ار ائهدهند كان خدمات سالمندان بوده است مواد و روش ها: اين مطالعه به روش مرورى-تطبيقى در سال Vهr| انجام شد. گردآورى اطلاعات به روش مطالعهى متون فراهم شده از كتابخانه ها و وبسايت سازمانهاى مرتبط كشورهاى منتخب بود. منابع مورد استفاده به زبانهاى فارسى و انخليسى و مربـوط

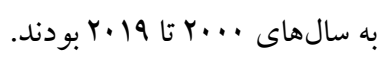
يافته ها: يافته ها حاكى از آن است كه سوئد و آمريكا زودتر با بِيده سالمندى جمعيت مواجـه شـدهانـد و خــدمات متنسوعترى بـا توجه به جنبههاى مختلف زندكى سالمندان و همجينين بوشش جمعيتى گستردهترى دارند. در ايران بسيارى از انسواع خـدمات مـورد

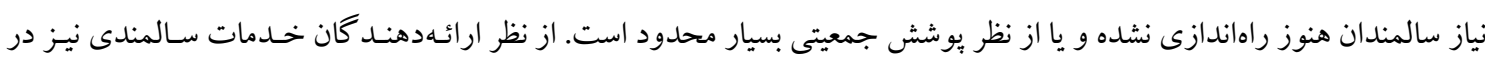

كشور ايران نسبت به سوئد و ايالات متحده آمريكا توجه كمترى به سازماندهى داو طلبان و ارائهدهند كان غيررسمى شده است. نتيجهَ Fيرى: بيشنهاد مى شود از تجارب كشورهاى موفق كه ييش از ايران با بحران سالمندى مواجه شدهاند درس بخيـريم. برخى

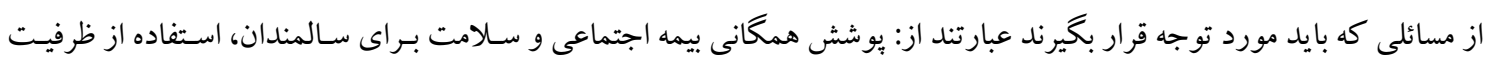
افراد داوطلب و بخش خصوصى، مر اقبت ادغاميافتـه بـا استفاده از تـيم بـين رشـتهاى، استفاده از فنـاورىهـاى نـوين بـراى خــدمات سالمندان، نيازسنجى و ظرفيت سازى براى آموزش نيروى انسانى و در نظر كرفتن حمايت هاى مالى و غيرمالى براى خانو ادههايى كه

از سالمندان خود مر اقبت مى كنند.

كليدوازهها: مطالعه تطبيقى، سالمند، خدمات سلامت سالمندان، مسكن سالمندان، بازنشستخى

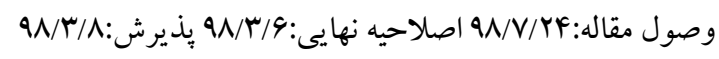


• 1\% جمعيت ايران را افراد بالاى •9 سال تشكيل دادهاند و.

در ها سال آينده اين مقدار به حدود بr/٪ افزايش ميابد (9). بنابراين، يكى از اصلىترين جالشهاى آينده ايران سالمندى

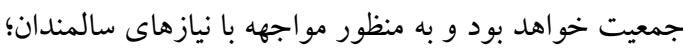
سياستخذارى، برنامهريزى، سرمايه گذارى و ايجاد زيرساختهاى لازم از امروز بايد مورد توجه قرار گيرد (V).

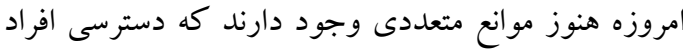
مسن به خدمات بهداشتى درمانى را محدود مى كنند، به خصوص در كشورهاى كم درآمد و در بين افراد محروم كشورهاى بردرآمد (Y). بنابراين اخر برنامهريزى مناسب صورت نخيرد در آينداى نزديك با حجم گستردهاى از مشكلات و ناكار آمدىها در مورد سالمندان مواجه خواهيم

استفاده از تجارب موفق كشورهايى كه قبلا سالمندى جمعيت را تجربه كردهاند در مطالعات مختلف ويشنهاد شده است. در سالهاى بيشين مطالعاتى با عنوانهاى (اسيستم خدمات ويزه سالمندى در كشورهاى آمريكا و زاين و ارائه شاخصهايى جهت تدوين برنامه راهبردى خدمات سالمندى

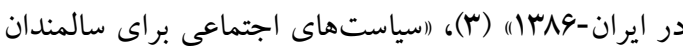

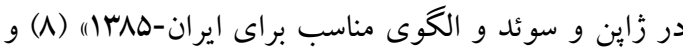
اخدمات مراقتى سالمندى در ايالات متحده آمريكا با نكاهى اجمالى به ايران-MYVV) (9) انجام شده كه خدمات

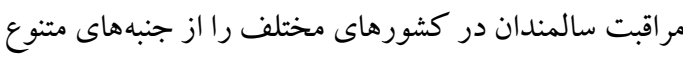

$$
\text { مورد بررسى قرار داده است. }
$$

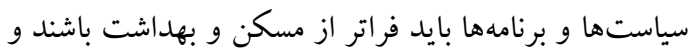

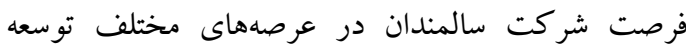

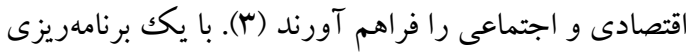
صحيح و بلندمدت مىتوان از بيامدهاى منفى سالمندى

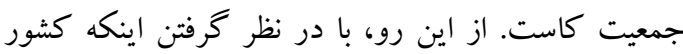

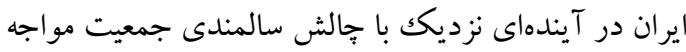

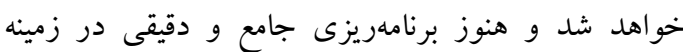
خدمات مراقبتى سالمندان انجام نشده، ضرورى به نظر فراع مىرسد كه با استفاده از اطلاعات به روز به بررسى ابعاد ارائه
مقدمه تغييراتى كه سالمندى يكك فرد را تشكيل مىدهند بسيار بيجيده هستند. از نظر بيولوزيك، سالمندى با تجميع تدريجى انواع مختلف آسيبهاى سلولى و مولكولى همراه

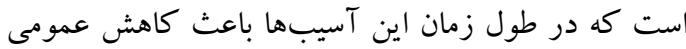
ظرفيت و تو انايى فرد مىشود (1). به همين دليل افراد سالمند به حمايتها و خدمات اجتماعى و بزشكى متعددى نياز دارند. نقاط كليدى براى فعاليت در زمينه سالمندى همراه با ليا سلامتى شامل تطبيق نظامهاى سلامت با نيازهاى جمعيت مسن، توسعه نظامها براى ارائه خدمات مراقبت بلندمدت، تضمين اينكه هر فردى مىتواند در يك محيط دوستدار سالمند يير شود و بهبود سنجش، بايش و ادراك در اين فردي زمينه مىباشد (Y). امروزه در كشورهاى بيشرفته به صورت

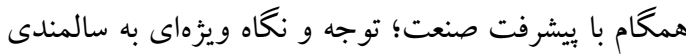
به عنوان يكك جمعيت رو به رشد كه نيازهاى ويزهاى دارند، مىشود و دولتها در جهت ارائه خدمات ويزه و هدايت

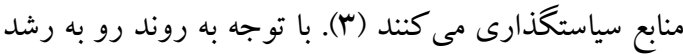
سالمندى جمعيت در ايران توجه ويزهه به سياستخارى و باني برنامهريزى براى رفاه سالمندان بسيار مورد اهميت است.

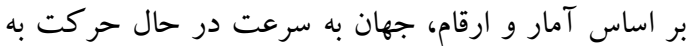
سمت سالمندى جمعيت است. در ايران نيز جمعيت سالمند در حال افزايش است و با ورود نسل انفجار نوزادان

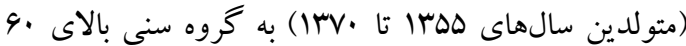
سال، ايران به يكى از كشورهاى داراى بيشترين سرعت رشد لهد جمعيت سالمند تبديل خواهد شد (f). بر اساس تعريفى كه افراد بالاى 90 سال را سالمند محسوب مى كند، جمعيت بهاب

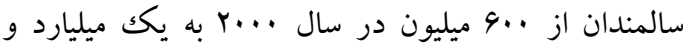
دويست ميليون يعنى دو برابر در سال هr.r خواهد رسيد

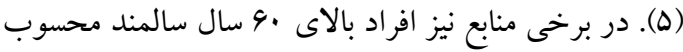

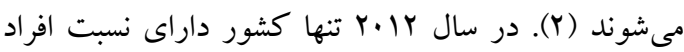
بالاى •9 سال بيش از •r درصد زاين بود ولى تا اواسط قرن

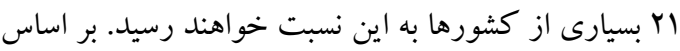
كزارش سازمان بهداشت جهانى در سال ها.ب نزديكك به

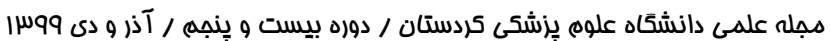


اين مطالعه از نوع كاربردى و به روش توصيفى-تطبيقى در

سال VIr انجام شد و جستجوى مطالب به مدت V ماه از

ابتداى تير 9V تا انتهاى دى 9V به طول انجاميد. در اين يزوهش، وضعيت خدمات مراقبت از سالمندان از جنبههاى مختلف (شامل اطلاعات دمو گرافيك، انواع خدمات ويزه سالمندان، ارائهدهندگًان خدمت) در كشورهاى منتخب، مقايسه شد. جامعه يُزوهش مجموعه مكتوبات و مستندات مرتبط با موضوع مطالعه بود. دادههاى مورد نياز از طريق جستجوى بيشرفته واز كان كليدى در بانككهاى اطلاعاتى انخليسى لئى و Scopus ،Science Direct ،Web of Science و و معادل فارسى آنها در بانككهاى اطلاعاتى SID Magiran عدم دستيابى به اطلاعات مورد نياز، جستجوى تكميلى در منابع علمى معتبر از جمله سايت وزارت بهداشت كشورهاى منتخب، يايخاههاى اطلاعرسانى، گزارشهاى منتشر شده، مراكز دانشگاهى و تحقيقاتى و گو گل سرج انجام شد.
خدمات سالمندان در كشورهاى منتخب و الهام گيرى از نقاط مـثبت و موفقيتهاى آنها و مقايسه با كشور ايران بيردازيم. كشورهاى منتخب در اين بزّوهش، آمريكا، سوئد و ايران بودند كه انتخاب آنها با استفاده از نظر متخصصان و به دلايل زير صورت گرفت: الف) اين سه كشور با درجات متفاوتى از يديده سالمندى مواجه هستند و هر كدام متناسب با نوع نظام ارائه خدمات اجتماعى و بهداشتى درمانى خود برنامهايى براى سالمندان دارند. ب) نظام سلامت ايران تا حدودى به كشورها آمريكا شباهت دارد (بوريج/تركيبى). ج) در دسترس بودن اطلاعات مورد نياز در مورد كشورهاى منتخب. د) كشورهاى سوئد و آمريكا وضعيت مناسبى از نظر ارائه خدمات به سالمندان دارند. نتايج اين مطالعه مى تواند به منظور طراحى خدمات مناسب براى سالمندان به كار كرفته شود و همجنين يك ديد كلى از وضعيت ارائه خدمات سالمندى در سه كشور ارائه مىدهد كه مىتواند مورد استفاده سياستخذاران در كشورهاى مختلف قرار كيرد.

مواد و روشها

جدول ا. استراتزى جستجو در هايكاههاى داده

استراتزى جستجو

טايكاه

((senior OR elderly) AND (care* OR service*)) AND ALL FIELDS: (provision) AND ALL FIELDS: (Sweden). ((senior OR elderly) AND (care* OR service*)) AND ALL FIELDS: (provision) AND ALL FIELDS: (Untied States*) OR (USA) OR (America*). ((senior OR elderly) AND (care* OR service*)) AND ALL FIELDS: (provision) AND ALL FIELDS:

Web of (Iran).

((senior OR elderly) AND (care* OR service*)) AND ((provision) AND (Sweden)). ((senior OR elderly) AND (care* OR service*)) AND ((provision) AND ((Untied States*) OR (USA) OR (America*))). ((senior OR elderly) AND (care* OR service*)) AND ((provision) AND

Science (Iran)).

((senior OR elderly) AND (care* OR service*)) AND ((provision) AND (Sweden)). ((senior OR elderly) AND (care* OR service*)) AND ((provision) AND ((Untied States*) OR (USA) OR $($ America*)) $)$. ((senior OR elderly) AND (care* OR service*)) AND ((provision) AND

Science (Iran)).

((senior OR elderly) AND (care* OR service*)) AND ((provision) AND (Sweden)). ((senior OR elderly) AND (care* OR service*)) AND ((provision) AND ((Untied States*) OR (USA) OR $($ America* $)))$. ((senior OR elderly) AND (care* OR service*)) AND ((provision) AND

Direct (Iran)).

\begin{tabular}{|c|c|}
\hline "خدمات سالمندان" يا "خدمات سالمندى" يا "سالمند" & Magira \\
\hline "خدمات سالمندان" يا "خدمات سالمندى" يا " & SID \\
\hline
\end{tabular}


وارد مطالعه شد و 4 مقالهى جديد نيز از فهرست منابع

مقالات مطالعه شده بازيابى شد. در مجموع با احتساب

مطالب سايتهاى معتبر، گزارشات و كتب مورد استفاده،

INV منبع وارد مطالعه كرديد. در نهايت اطلاعات

جمع آورى شده بر اساس سوالات تحقيق تفكيك شده و

مورد مطالعه دقيق قرار گرفت و در قالب جداولى كه از

بيش به منظور تطبيق نتايج تهيه شده بودند تنظيم شد و به اين

ترتيب با نظم دادن به اطلاعات، تشابهات و تفاوتهاى

$$
\text { مربوط به خدمات مراقبت از سالمندان مشخص گرديد. }
$$

در شكل ا به طور كامل فرايند دستيابى به منابع مورد استفاده در اين مقاله شرح داده شده است. منابع مورد استفاده

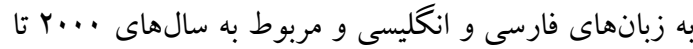
19 ب بودند. معيار ورود، تمامى مطالعاتى بود كه ارائهى خدمات مراقبت سالمندان را در كشورهاى منتخب بررسى كرده باشند. معيار خروج عدم دسترسى به متن كامل منابع بود. جُكيدهها را دو بزوهشخر از نظر كيفيت و ارتباط با موضوع بررسى كردند و درنهايت FrV مقالهى مرتبط جمع آورى شد. در مرحله بعل، يس از مطالعه متن كامل مطالعات و حذف موارد تكرارى و غير مرتبط، ب+1 مقاله

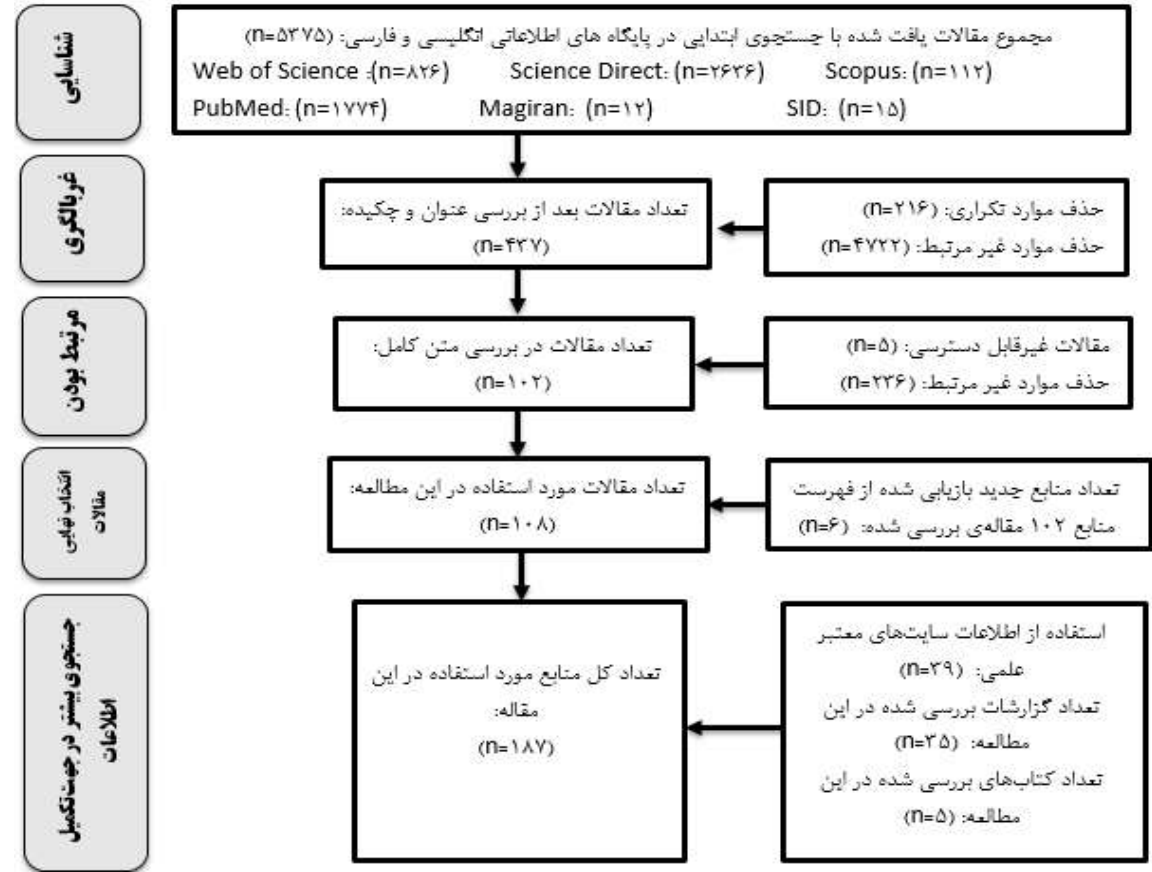

شكل ا. فلودياكرام فرايند شناسايع، غربالكرى و انتخاب منابع مورد استفاده در مطالعه

جدول r. مقايسه اطلاعات دموكر افيكى كشورهاى منتخب و ايران

\begin{tabular}{|c|c|c|c|}
\hline 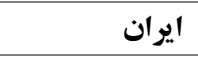 & سوئد & آمريكا & \\
\hline 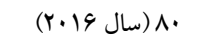 & 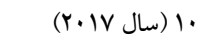 & 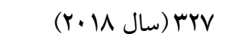 & جمعيت كل كشور (ميليون نفر) \\
\hline ( & 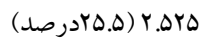 & (1.0)99.VVF & جمعيت بالاى •ع سال در سال Pr P \\
\hline 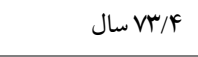 & 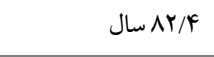 & سال VN/9 & نرخ اميد به زندكى در سال 1 أr \\
\hline
\end{tabular}

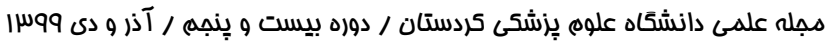




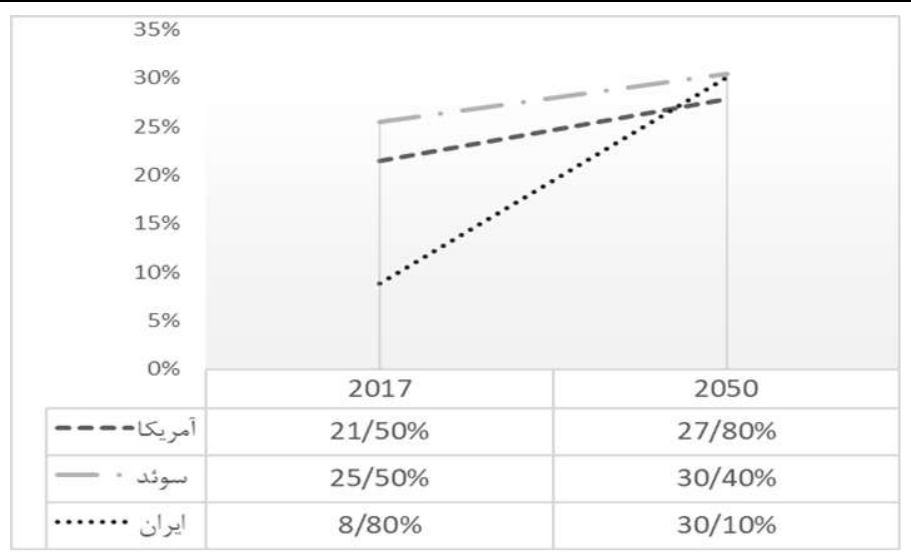

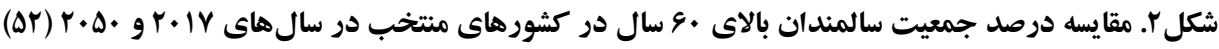

مى دهد كه شامل 9 اسـتاندارد عمليـاتى اسـت. تـا بـه امـروز،

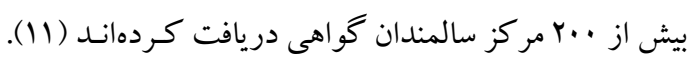

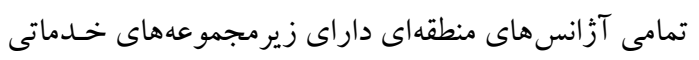

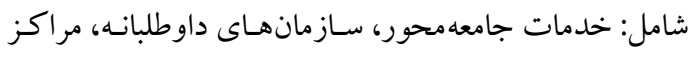
سالمندان جندمنظوره، معاونت حقـوقى، خـدمات دسترسى،

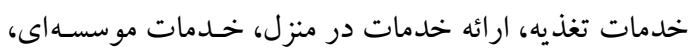

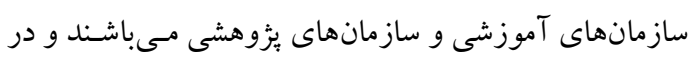

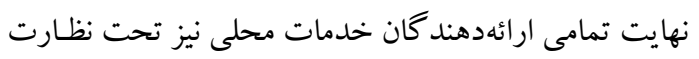
و كنترل سازمانهاى منطقهاى هستند (Y)

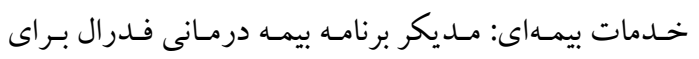

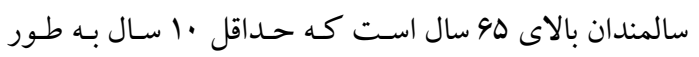

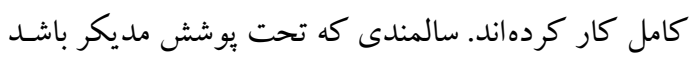

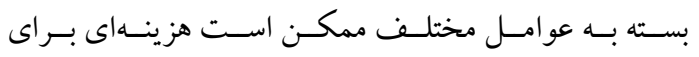

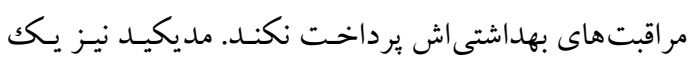

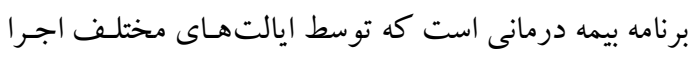
مىشود و بخشى از آن توسط دولت فدرال تامين مسى شـود.

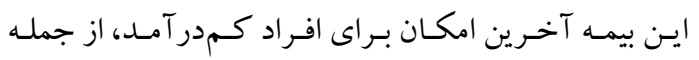

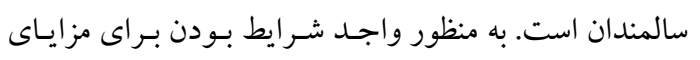

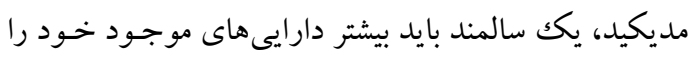

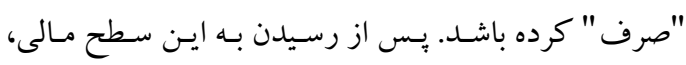

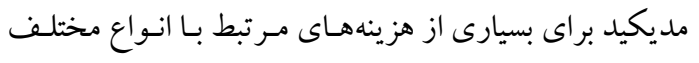

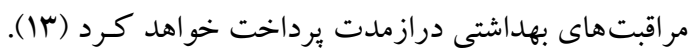

يافته ها اطلاعات دمو گرافيك كشورهاى مورد مطالعه: اطلاعات

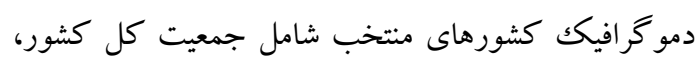

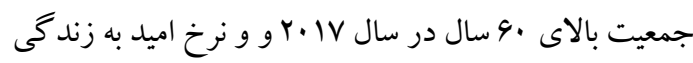
در جدول r ارائه شده است. در شكل r بنيز سرعت رشد نسبت جمعيت سالمندان در كشورهاى منتخب بين سالهاى

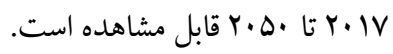
انواع خدمات سالمندان

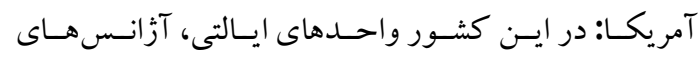

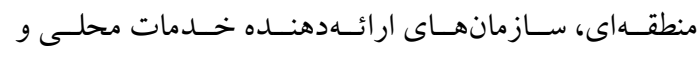

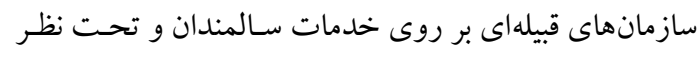

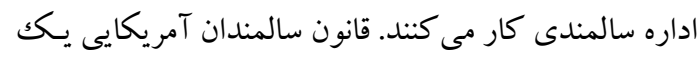

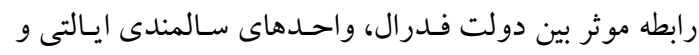

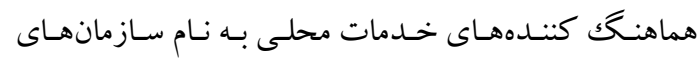

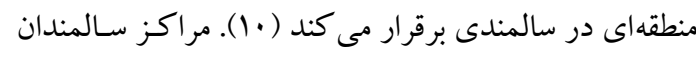

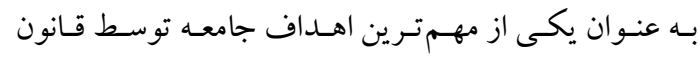

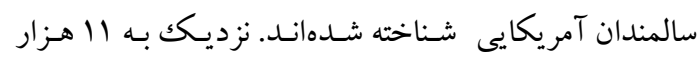

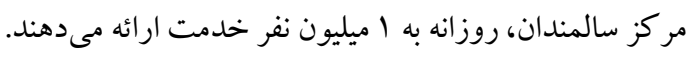

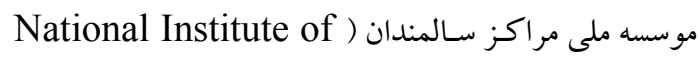
(Senior Centers

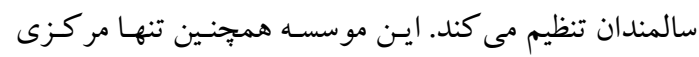

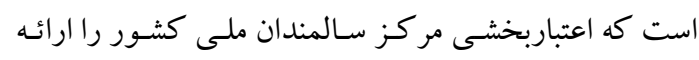


آسايشـاهى؟ بيمارسـتان و مر اقبـت برسـتارى در منـزل در

$$
\text { صورت لزوم (10) - (10). }
$$

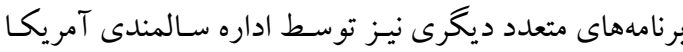

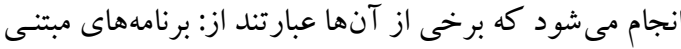

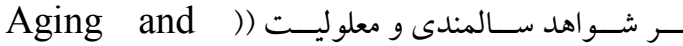

Disability Evidence-Based Programs and Practices (ADEPP)، سلامت رفتارى، سـلامت مغز، برنامـهـهـاى آمـوزش خودمـــيريتى بيمـارىهـاى مـزمن،

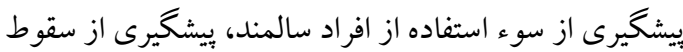
(افتادن)، كمككهاى حقوقى، بهبود مـديكر بـراى بيمـاران و

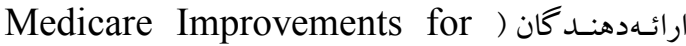
(Patients and Providers (MIPPA) حمايست از مراقبـان خـانوادگى ( National Family ، (Caregiver Support Program (NFCSP) برنامهـريزى فردمحسور، حمايـت از افراد مبـتلا بـه دمانس،

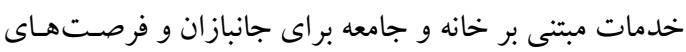
داوطلبانه و مشار كت مدنى (19). علاوه بر موارد فوق برنامـهـ مكانياب مراقبت سالمندان نيز يكك سرويس سراسرى است

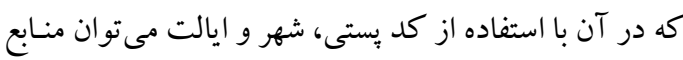
ارائه خدمات به سالمندان؛ خدماتى مانند وعدههـاى غـذايى، مراقبت در منزل يـا حمـل و نقـل، نيـاز بـه مراقـب و نيـاز بـهـ

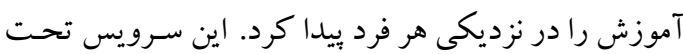

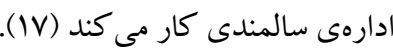

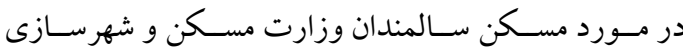

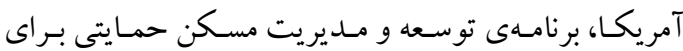

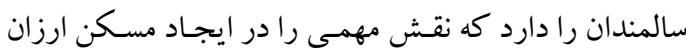

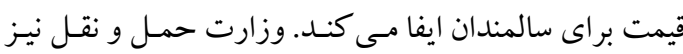
برنامهى افزايش تحر كك براى افراد سالمند و داراى معلوليت

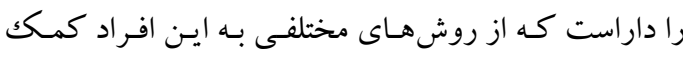

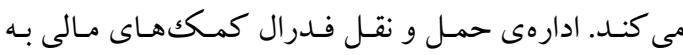

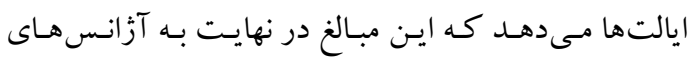
ارائهدهندهى محلى مىرسند و صرف خريد وسايل نقليه در
علاوه بر موارد فوق، انواعى از طر حهـاى بيمـهى خصوصى نيز براى سالمندان موجود است (11). زندگى حمايتى: يك گزينه مراقبتهـاى بهداشتى درمـانى

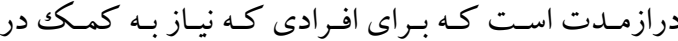
فعاليتهاى روزمره مانند غذا، حمام كردن و لباس يوشيدن، مديريت داروها و غيره دارند طراحى شده است. بـيش از 19 درصد ساكنان زندگى حمايتى هزينه اجـاره و خـدمات را از

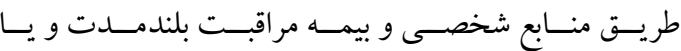

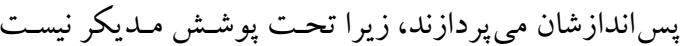

خانههاى يرستارى: خانههاى يرستارى مراقبت هـاى بـازتوانى

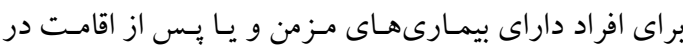

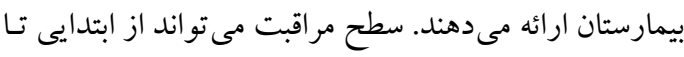

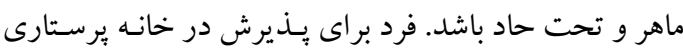

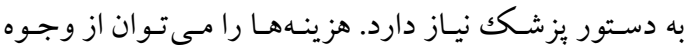
خصوصى، سياستهاى بيمه مر اقبت بلندمدت و /يا مـديكر و

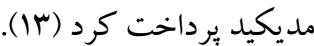

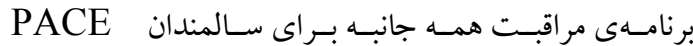
(Program of All-Inclusive Care for the (Elderly)) بـراى برخسى از افـراد ضـعيف و افـراد مسـن جامعـه فـراهم مى كند. يكك تيم بين رشتهاى از متخصصين سلامت، به افراد

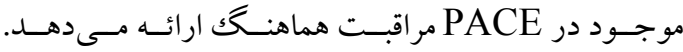
معيارهاى واجد شرايط بودن براى اين برنامـه شـامل سـن هذها

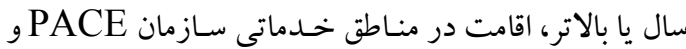
واجد شـرايط بـودن بـراى مراقبـت برستارى در خانه اسـت (F) (1). برخى از خدمات اين برنامه عبارتند از: مر اقبت روزانه ئه

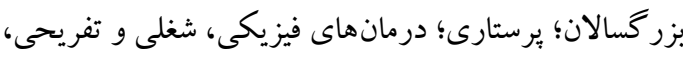

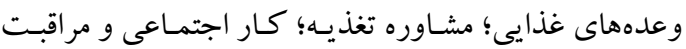

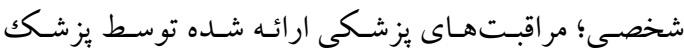

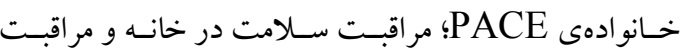

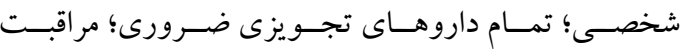


خانو ادههـا نيـز هسـتند، از قبيـل ارائهه مزايـا بـهـ بســـانى كـهـ مراقبت هاى يزشكى خانكى ارائه مى دهند (YF). اين خدمات به مر اقبان غيررسمى مى تواند توسط سـازمانهـاى داوطلب غير رسمى مانند صليب سرخ نيز فر اهم شود (YD). بـه طـور كلى انـواع مــلـهـاى مسـكن سـالمندان در سـوئد عبارتند از: () زندگى در خانه و دريافت خدمات مراقبت در منزل، دريافت هشدار امنيتى و همجينين تطبيق خانه با نيازهاى فرد. Y) مسكن سالمند (Senior living) يـا مسكن بـالاى ها ساله كه هدف آن سالمندان فعال مسىباشـد. آيارتمـانهـا

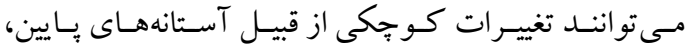
اجاقهاى در دسترستر و غيره داشته باشند. r) مسـكن ايمـن مشابه مسـكن بـالاى هاه سـاله و مسـكن (Secure living) سالمندان است، اما ساكن بايسـ بـيش از · لسـال سـن داشـته باشد. اين ساختمان داراى يك منطقه مشتركك، زنگك هشدار اضطرارى در هر آيارتمـان و امكـان دريافت غـذا اسـت. F) خانه برستارى: براى افرادى كه نسبت بـه كسـانيكه در منـزل خودشان زندگى مى كنند به مراقبت بيشترى نياز دارنـد ارائهـ مىشود. انواع مختلف خانه هاى برستارى وجود دارد. يرسنل يرستارى و يرسنل خدمات به صورت TF سـاعته در دسترس

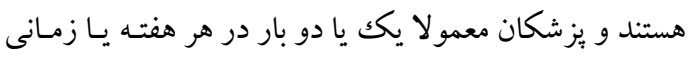
كه مورد نياز هسـتند، مسى آينـد. ه) مراقبـتهـاى تخصصى: . شامل همه انـواع مراقبـتهــاى تخصصى، بـراى مثـال، زوال عقل، آلزايمر و سرطان است. بيمـار در يـك خانـه يرستارى كه براى بيمـارىهـاى خـاص تخصص يافتـه است زنـدكى

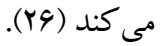
سيستم بازنشستخى سالمندان شامل حقوق بازنشستگى مبتنى بر در آمد و حقوق بازنشستخى حق بيمه است. همجينين شامل

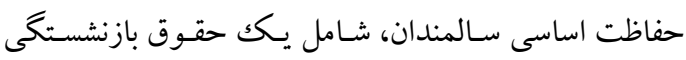

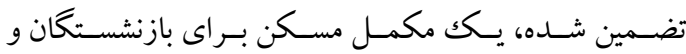
يشتيبانى نگهلارى براى سالمندان است. علاوه بر اين، ياداش براى وابستخان، شامل حقوق بازنشستكى تنظيم شده، حقـوق
دسترس مانند وسايل نقليـه بـا بـالابر بـراى ارائهـ خــدمات بــه سالمندان و معلولان مىشود (1) ). سوئد: نظام مراقبت سالمندان سوئد همشانى است كه در آن به همه ساكنان قانونى، صرف نظر از در آمد يا اشـتغال قبلى، حق خدمات مراقبتى بـه منظور رفـع نيازهايشـان را مسىدهـد (19). تعداد شهروندان سالمند كـه يكـى از دو نـوع مراقبـت سالمندان (كمكك در محيط خانه، و مراقبت هاى موسسهاى يا

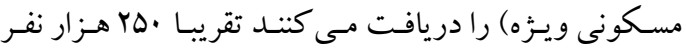
است، كه برابر با ها درصد از تمـام مسـتمرى بكيـران بـالاى 90 سـال اسـت. حـدود ه9 هـزار نفــر از ايـنهـا در نـوعى از امكانات سازمانى زندگى مى كنند (·) در سوئد دسترسى به مر اقبتهاى اجتماعى بر اسـاس نيازهـاى بيان شده است كه توسط يكك مدير مراقبتى كه در اداره رفاه اجتماعى شهردارى كار مى كند، ارزيابى مى شود. فرايندهاى

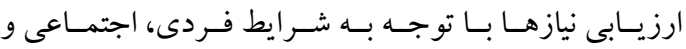
خـانوادگى گيرنــــان مراقبـت، از طريـق مصـاحبه بـا فـرد درخواست كننده سازماندهى مىشود ( (Y). در سالهاى اخير تـا حسدودى جيـرهبنـدى خـدمات بـهـ وجـود آمـده اسـت و دريافـت كنتـد كان كمـك كهـاى خـانكى يشـتيبانى كمتــى

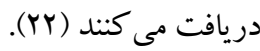
مر اقبـت سـالمندان در سـوئد شـامل هـر دو نــوع خــدمت كمككهاى خانكى و مراقبتهاى موسسهاى يا مسكونى ويثه (خانههاى سالمندان، خانههاى برستارى و غيره) اسـت ( (Y). 49 درصد از خدمات اجتماعى به صورت كمكك در منزل و سب درصد از خـدمات اجتمـاعى در مسـكنهـاى ويـزه ارائهـ مسىشـوند (Yr). شـهردارىهـا و بـه طـور فز اينـدهاى بخـش خصوصى، خدمات كمككهاى خـانكى، نظير تميز كردن، شستوشو، خريد و غيره و همجنين مراقبت هاى اجتمـاعى را

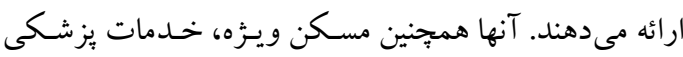
در منــزل، غـذا روى جــرخ (meals on wheels)، هشدارهاى ايمنى شخصى، ساز گارى خانه و خـدمات حمـل و نقــل ارائسه مسى دهنـــ. شــهردارىهــا مسـئول حمايــت از 
ابعاد. ه) مناسبسازى محيط شهرى و مسكونى معلولان و

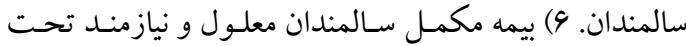

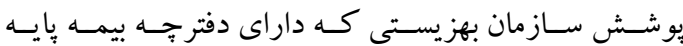
باشند(V). ارائه خدمات اجتماعى به گيرند كان خدمت تحت يوشش شامل كمككهاى مستمر و غير مستمر به خانو ادههـاى

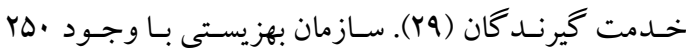
مركز نخهارى شبانهروزى، روزانه، جامع و مراقبت در منزل بهري

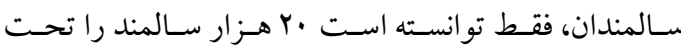
يوشش مراكز خود قرار دهد (·r). براساس كزارش سـازمان

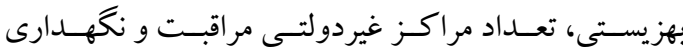

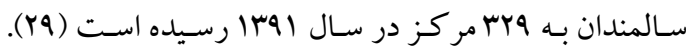

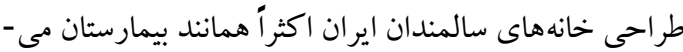

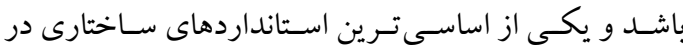
خانههاى سالمندان كه شباهت هرجه بيشتر خانه سـالمندان بـا

خانه خود سالمند است، در آنها رعايت نشده است (آم). از نظر يوشش بيمهاى، مطالعات انجام شده نشان مىدهد كـه

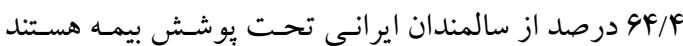

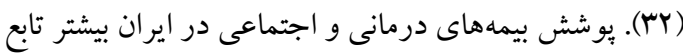
وضع شغلى افراد است و در مورد بيمـهــاى حمـايتى و نيمـهـ

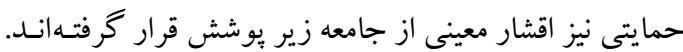

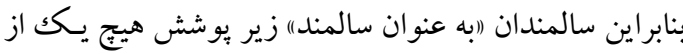
سازمانهاى بيمهاى نيستند. حمايتهـاى موجـود بـراى افراد

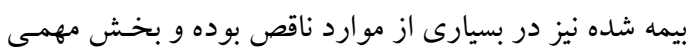

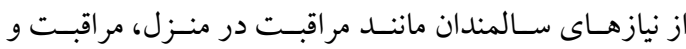

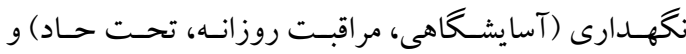

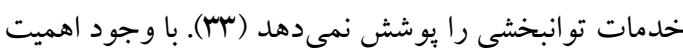

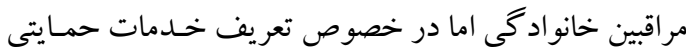

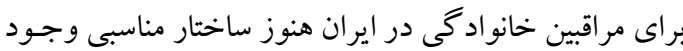

ندارد (q).

شبكه ملى خدمات سالمندى انجام مىدهـــ ايـن زيرسـاخت

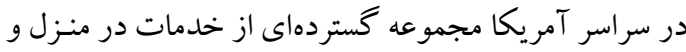
مبتنى بر جامعه را براى بيش از ^ميليون سـالمند در هـر سـال
بازنشستخى بيوه و بازنشستخى ويزه بازمانـد گان، وجود دارد

برخى از كاربردهـاى فنـاورى اطلاعـات در مراقبـت و ارائه خدمات درمانى به سالمندان سوئد شـامل مـوارد زيـر اسـت: خدمات توانبخشى، مر اقبتهاى يزشكى در منـازل، خـدمات

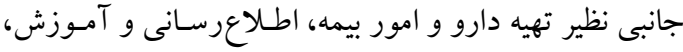
اجر اي درمان، بيخيـيرى درمـان و نظارت بـر نحوه درمـان و

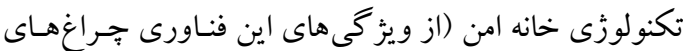
اتوماتيك است. با استفاده از سنسورهاى خاصى كه در نقاط مختلف منزل نصب مىشود، و صداهاى از يِي ضبط شـده،

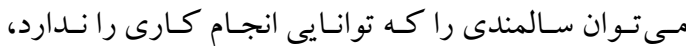
راهنمايى نموده و وضعيت و موقعيت سالمند را كنترل نمود)

ايـران: بـه طسور كلى سـازمان بهزيستى تحـت نظـر وزارت تعاون، كار و رفاه اجتماعى به عنوان متولى اصلى نظام تامين اجتماعى ايران، خدمات خود به سالمندان را در قالب مـوارد ذيل ارائه مى دهد: () مراكز نخهدارى از سالمندان: از طريق ارائه مجوز، اعطاى يارانه و نظارت. خدمات اين مراكز شامل

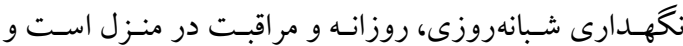
مر اقبت هايى از قبيل انجـام امـور تغذيـه، نظافتـ، استحمام، يوشاندن لباس، مراقبت هاى بهداشتى درمانى، داروئى، امور توانبخى و ايجاد زمينه هاى سر گرمى و بهره گيرى از اوقات فر اغت به سالمندان ارائه مسىشـود. Y) برنامـهـاى آموزشى

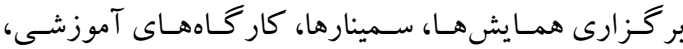

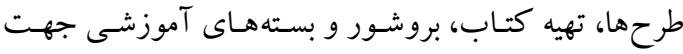
آموزش مسئولين مراكز، كارشناسان، كادر خدمتدهنده بـهـ سالمندان، ميانسالان و خانو اده سالمندان. r) انجام تحقيقـات در زمينـه سـالمندان F) تو انمندسـازى سـالمندان شـهرى و

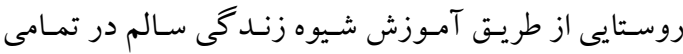

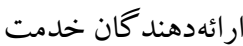

آمريكا: اداره سالمندى كه بازوى وزارت بهداشـت در ارائه

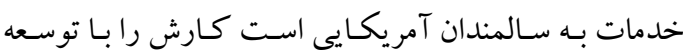


مــد كار ان اجتمـاعى طـب سـالمندى و مرييـان بـالينى (كـهـ ممكن است در بيمارستانها و دانشكاهها هماهنگك كنــدهى ارائه آموزش ها باشند) (هץ). در خانه هاى يرستارى، مر اقبـت بايد توسط برستاران ثبت شده (RNs) يا يرستاران عملياتى مجاز (LPNs) ارائه شود (•) المان سـوئد: در سـوئد وزارت سـلامت و امـور اجتمـاعى مسـئول مسائل مربوط به رفاه جامعه است. ارائه مر اقبـت و ارائهـ بيمـهـ بــراى تـامين امنيـت مــالى ســالمندان و همجنــين سيسـتم بازنشستخى سـالمندان نيز از مسئوليت هـاى ايـن وزارتخانهـ مس باشــ (YV). در سطح ملى، دولـت و يارلمـان مسئوليت

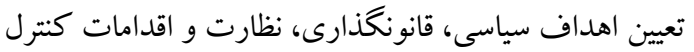

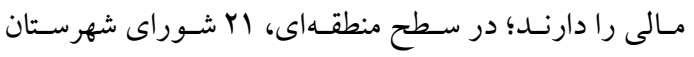

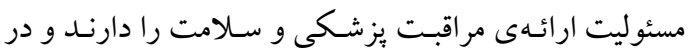

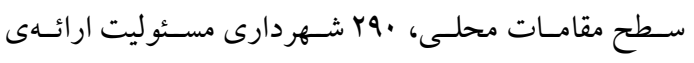

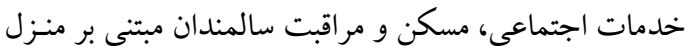

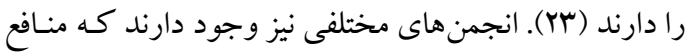

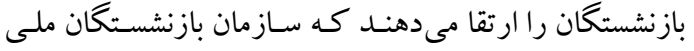
بزر گترين آنها اسـت (PRO)

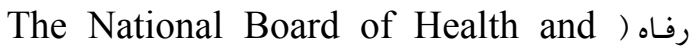
نيز مسئول بـايش و بازرسى از طريق نظـارت، (Welfare

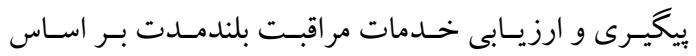

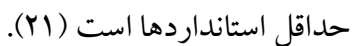

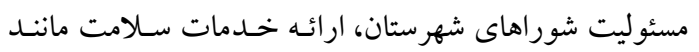
بيمارستانها، مراكز سلامت و ساير نهادهـا اسـت، درحاليكهـ مسئوليت شهردارىها تمام جنبههاى ديخـر مراقبـت از جملـه

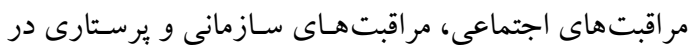

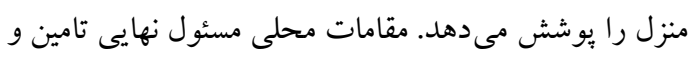

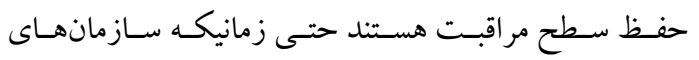

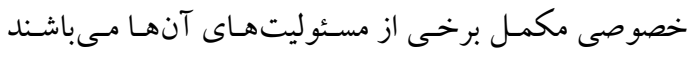

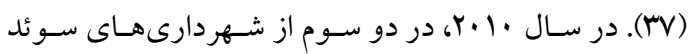

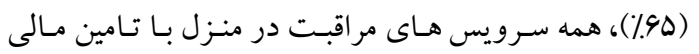

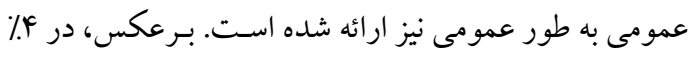

فر اهم مى كند. همجِنين خدمات مستقيم را سالانه بـه بـيش از .9. هزار مر اقبت دهندهى غير رسمى كه از عزيزان خهود در خانه نخهدارى مى كنند، ارائه مى دهد. شبكه ملى سـالمندى بزر گترين شبكه ارائه دهنـده مراقبـت درازمـدت در آمريكا فها

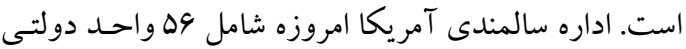
در زمينه سالمندى، لوه آزانس منطقهاى در زمينه سالمندى،

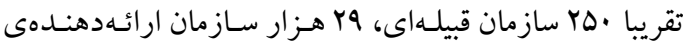

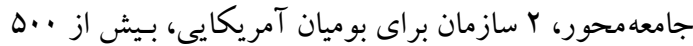

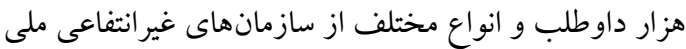
مىباشد (·) (1).

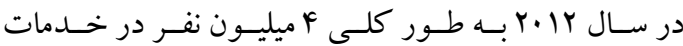
سالمندان آمريكا فعاليت داشتند كه ؟.ب ميليون نفر در ارائه خدمات مستقيم به سالمندان توسط آزانسها و ارائهدهند كان مختلف استخدام شده بودند و ..1هزار ارائهدهندهى مستقل خــدمات نيـز وجـود داشـته اسـت. از جملـه كسـانيكه بـراى آزانسها و تسهيلات ديخر كار مى كردند شـامل هـ اميليـون

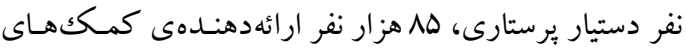

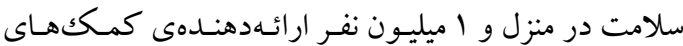

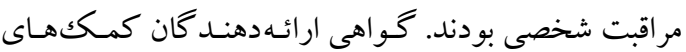

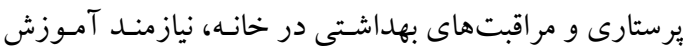

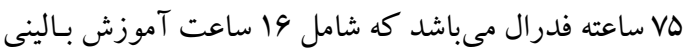
است. تمامى كار كنان آموزش هاى خاصى را بايـد بحذرانـد

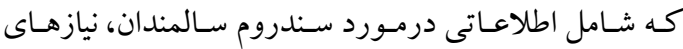

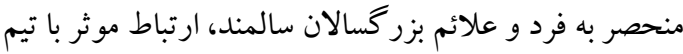
مر اقبت هاى بين رشتهاى، مصرف كنند كان و اعضاى خانواده

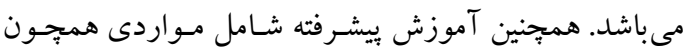

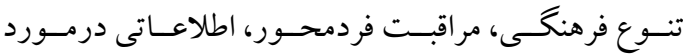

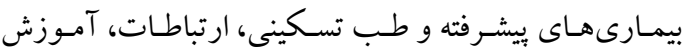
درمورد بيمارىها و مداخلات درمانى مىشود (YY).

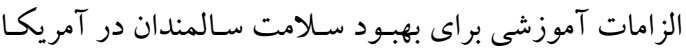

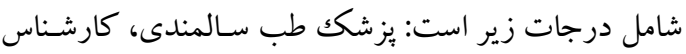
يرستارى طب سالمندى، متخصص داروساز طب سـالمندى، 
عسل السادات نيارئيس زواره

فعاليت مى كنند (Y9). از ديخــ نهادهـاى تاثير گذذار در امـور

سالمندان در ايران شوراى ملى سالمندان است كه به رياسـت وزير تعاون، كار و رفـاه اجتمـاعى و دبيـرى رئيس سـازمان

$$
\text { بهزيستى كشور تشكيل شده است (سF). }
$$

به طور كلى آسايشگاه سالمندان در ايران از نظر مالكيـت بـهـ جهار دسته قابل تقسيمبنـدى اسـت: () آسايشـاه سـالمندان دولتسى كـه زيسـر نظـر سـازمان بهزيسـتى اسـت و در آن از سالمندان بى يناه، درماندگان و بيمار ان طى شرايطى بـــير ايى مى كنند. Y) T آسايشگاههاى سالمندانى كه صرفا جنبـه خيريـه دارند. ب) آسايشگاههاى سالمندانى كه بـه صسورت خيريسه و شهريهدار تواما اداره مىشوند. F) آسايشـاههـايى كـه جنبـه خصوصى دارند و با مبالغ ماهانـهاى كـه از اوليـاى سـالمندان

$$
\text { مى گيرند اداره مىشوند (FF). }
$$

در ايسران برنامسه مراقبـت در منـزل توسـط بخـش خصوصى

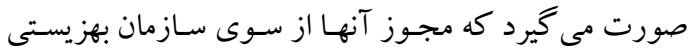

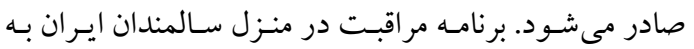
صـورت جـامع و بـر اسـاس اسـتانداردها انجـام نمسىشـود و همجينين دربر گيرنده كليه سالمندان نيازمند مراقبت نمىباشد (\&ه). علاوه بر ايـن، بسـته خـدماتى فعلى برنامـه مراقبـت در منزل سازمان بهزيستى نه تنها شامل خدمات حمـايتى (انجـام امور منزل، بازسازى و مناسب سازى) نمسىباشـد، بلكه حتى مراقبتهـاى فردى در سـطح مر اقبـتهـاى وايسه را نيـز ارائهـ نمى كند (F4). معاونت آموزشى وزارت بهداشت با مشار كت اداره سـلامت سالمندان به راهاندازى بر نامههاى آموزشى منجـر بـه مــدرك ويزه سالمندان از قبيل طـب سـالمندان، برسـتارى سـالمندان، مدد كارى اجتمـاعى سـالمندان، اييـدميولوزى، روانيزشـكى، تو انبخشىى، شـنوايى ســنجى، طـب تسـكينى، داروشناسـى، دندانيز شكى سالمندان اقدام نموده است و برنامـهـــيى بـراى روانشناسـى و مــدد كارى ويـرّه سـالمندى در دسـت اقـدام

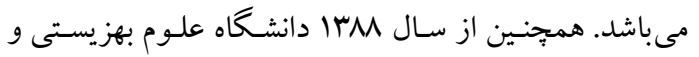
توانبخشى با همكارى دانشكاه علوم بزشـكى ايـران اقــام بـــ
از شهردارى ها، بيش از نيمى از خدمات مراقبت در منززل بـه طور خصوصى ارائه شده اسـت. بنـابر اين، در رشـت ميـانگين ملى ارائه خدمت خصوصى، تنوع زيـادى وجـود دارد (rی).

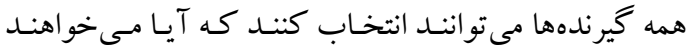
كمككهاى خانكى يا مسكن ويـزّه توسـط عو امـل دولتى يـا خصوصى ارائه شوند. تعداد شر كتهاى خصوصى در بخش خدمات اجتماعى در بين سالهاى 1990 اتـا هـ •. بــنج برابـر شده است (وس). كمككهاى غير رسمى و مشاركت داوطلبانه نيز منابع نسبتا مهمى به عنوان ارائهدهنـده كمـك و مراقبـت هستند (F). طبق برخى بر آوردها (ه · Y)، · ا درصد از كاركنان مراقبت درازمدت داراى مداركك تحصيلى در زمينه امـور بهداشـتى لــ درمـانى و اجتمـاعى هسـتند و •9 درصـد ديخـر نيـز دسـتيار يرستار و دستيار خانكى هستند. در نتيجه سوئد از نظر عرضسه

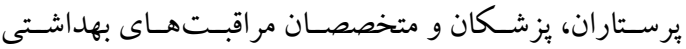

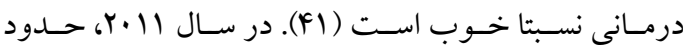

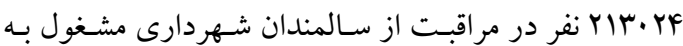
كـار بودنــد و بزر گتــرين گـروه حرفـهاى شـامل دسـتياران

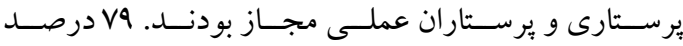
تحصـيلات رسـمى داشـتند، در حسالى كـه نسـبت در بـين

شهردارىها از هr تا . . ا درصد متغير بوده است (FY). اير ان: بخش عمده سازمانهـا و نهـادهـاى خــدمت دهنــده بـه سالمندان زيرمجموعه وزارت تعاون، كار و رفاه اجتمـاعى و يا به نحـوى مـرتبط بـا آن هستـند. سـازمان بهزيسـتى كشـور تحـت نظـر ايسن وزارتخانسه در كنـار سـاير وظـايف خـود، مسئوليت نخهــدارى از سـالمندان نيازمنــد را بـه عهـده دارد. وزارت بهداشـت، درمـان و آمـوزش بزشـكى نيـز بـه لحـاظ مسـئوليتى كـهـه در قبـال حفـظ و ســلامت شـهروندان دارد، اقداماتى را نيز در زمينـه سـلامت سـالمندان بـه وسـيله اداره سالمندان انجام مى دهد. علاوه بر دستخاههاى دولتى، نهادهـا و سازمانهاى غيردولتى متعددى از جمله كميته امداد نيـز بـهـ منظـور حمايـت از سـالمندان و مر اقبـت و نخهــدارى آنـان

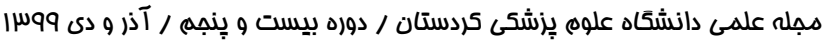


در جـدول ب بـه طـور خلاصـه بـه مقايسـهى انسواع خــدمات

مراقبت سالمندان و ار ائهدهندگان خدمات برداختهايم.

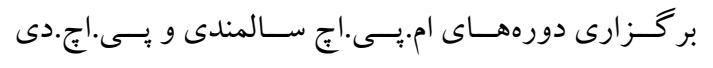

سالمندشناسى نموده است (سT).

\section{جدول "ا. مقايسهى ارائهدهندكان و خدمات مراقبت سالمندان در كشورهاى منتخب}

\begin{tabular}{|c|c|}
\hline 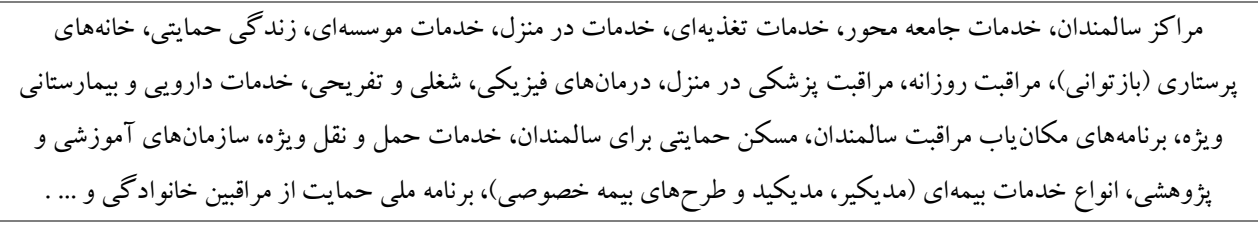 & 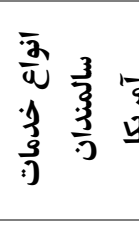 \\
\hline 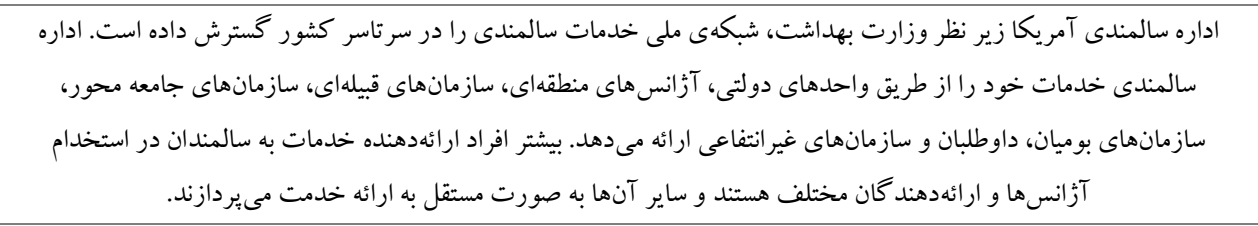 & 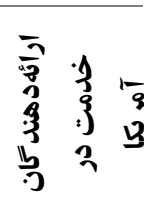 \\
\hline 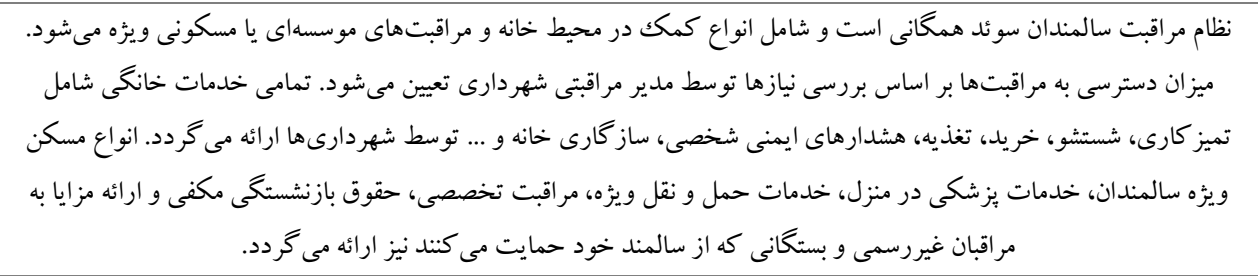 & 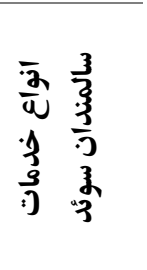 \\
\hline 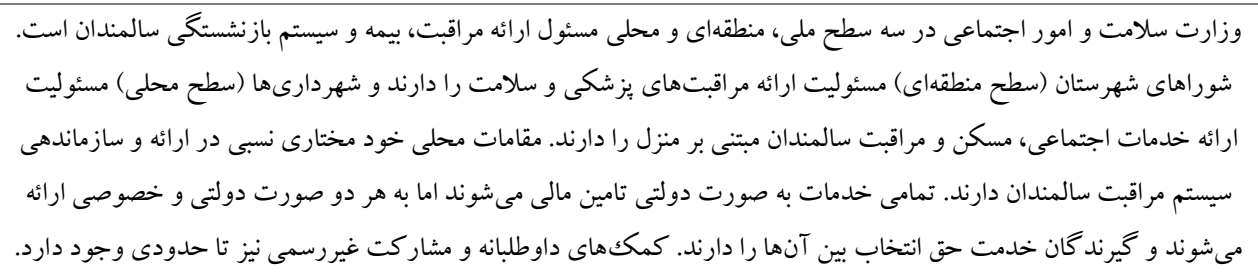 & 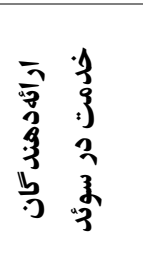 \\
\hline 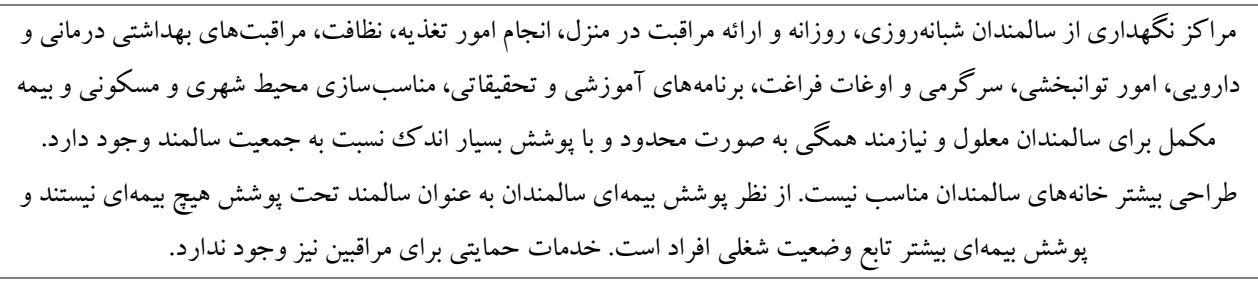 & $\begin{array}{ll}\overline{2} & \frac{3}{3} \\
\bar{w} & \frac{3}{3} \\
1 & \frac{3}{3} \\
3 & \frac{3}{3} \\
\vdots & \frac{1}{3}\end{array}$ \\
\hline 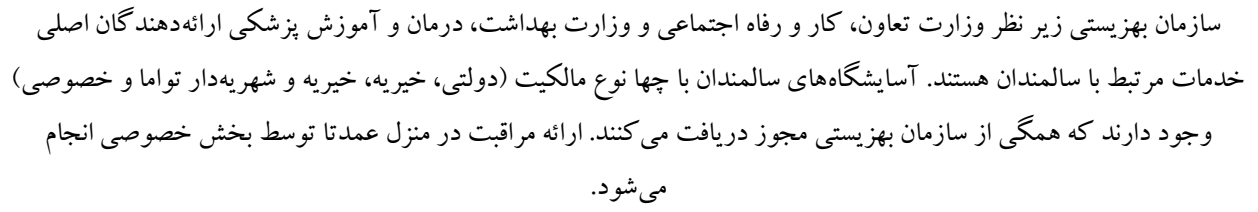 & 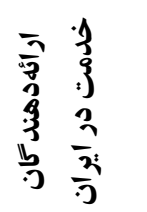 \\
\hline
\end{tabular}


عسل السادات نيا رئيس زواره هرا

هماهنـگ و غيـر منسـم (non-coherent) ار ائسه مسى كنــ بحث

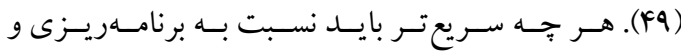

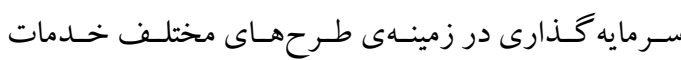
سالمندى در ايران اقدامات مناسب به عمل آيد.

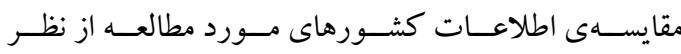

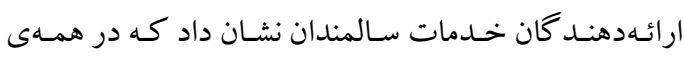
كشورها دولت ار ائه دهنده رسمى اصلى مىباشـد، امـا نقـش مراقبان خانواد گى نيز بسيار بررنگگ است. در كشور آمريكا

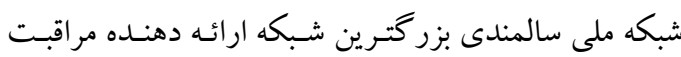
درازمدت و بازوى وزارت بهداشت اسـت كـه تمـامى ارائه دهندگان دولتى، خصوصى و داوطلب زيـر نظر ايسن شـبكه فعاليت مى كنند. در سـوئد نيز كـه يـك نظـام سوسياليستى دارد، مسـئوليت مراقبـت از سـالمندان در سـه سـطح ملى، منطقهاى و محلى تقسيم مىشود و تمام تصميمات مربوط بــ حمايت از سـالمندان (جـه خصو صسى و جـهـ دولتىى) توسط مدير خدمات مراقبتى شهردارى گرفته مسىشـود، امـا عمـده خدمات توسـط بخـش دولتى ارائه مسى شـود. امـا در ايـران

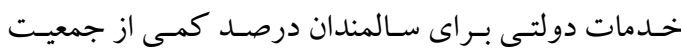
سالمند را بوشش مى مهد و بيشتر بار ارائهه خـدمات بـر روى

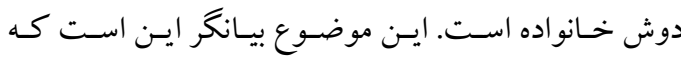
كشـورهاى توسعهه يافتـه كـه زودتــ از كشـورهاى درحسال توسعه با بديــده سـالمندى جمعيـت مواجـه شـدهانـد، شـبكه خدمات سالمندان وسـيع تـر و سـازمان يافتـهتـرى دارنــ كـه عمدتا توسط دولت سـازماندهى و ارائه مسىشـود. در نتيجـه كشورهايى مثل ايران مى توانند بـراى طراحسى الخــى ارائه خدمات سالمندان از تجارب كشـورهايى كـهـ زودتـر بـا ايـن

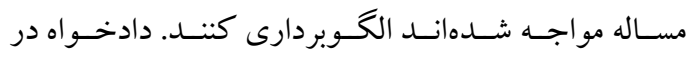

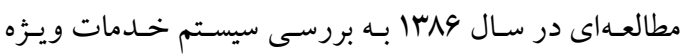

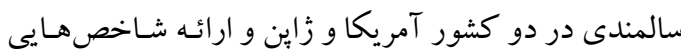
جهت تدوين برنامـه راهبـردى خـدمات سـالمندى در ايـران برداختـه اسـت. وى در ايـن مطالعـه بيـان كـرده اسـت كـهـ

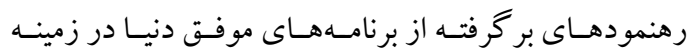
مقايسـهى دادههـاى دمو گر افيكك كشـورهاى مـورد مطالعـه نشان داد كه در ارتباط با جمعيت فعلى سالمندان كشـورهاى آمريكا و سوئد به دوران سالمندى جمعيـت رسيدهانـد، امـا كشور ايران هنوز در ابتداى مسير سالمندى جمعيت اسـت و در سالهاى آتى با بحران جدى مواجه خو اهند شد. آهنـگ سرعت رشد سالمندان در طى سالهاى آتى در ايـران بسـيار بالا خو اهد بود. در مطالعه ميرزايى و همكاران (9 هبا1) نيز به

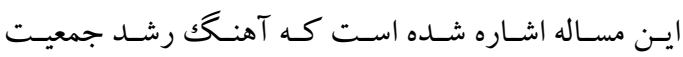
سالمندان در كشورهاى بيشرفته طى . . ا تا . . ب سـال اتفـاق افتاده است، درحاليكه در كشـورهاى در حـال توسـعه مانـــ

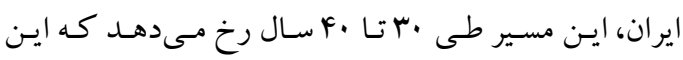
موضوع مشكلات متعـددى را بـه خصسوص در زمينه تـأمين مخارج سلامت سالمندان به همراه خو اهد داشـت (FV). ايسن موضوع بيديدهى سالمندى را به مشكل عميق ترى در كشـور

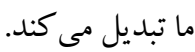
يافته هاى مطالعه حاضر نشان داد كه از نظر موجـود بـودن و دسترسى به خدمات ويثزه سـالمندان در دو كشـور آمريكاو سوئد خدمات متنوعى از جمله مراقبت مسكونى، مراقبت در منزل، خدمات سلامت، امكانات شهرى، حمايتهاى مالى و

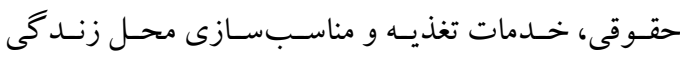

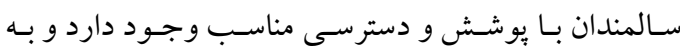
بسيارى از جنبه هاى زندگى سالمندان توجه شـده اسـت. امـا ايران هم از نظر تنوع خدمات سالمندان و هـم از نظر ميـزان يوشش در وضعيت مناسبى قرار ندارد. در مطالعهى فروغـان

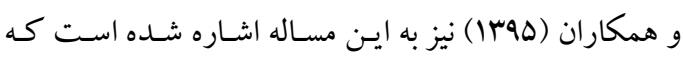
بسيارى از طرحهاى مراقبتى يا هنوز در ايران طراحى نشـده يا از نظر كمى بسيار اندك هستند، بطوريكه حتى سـالمندان متمكن نيز به سادكى نمى تو انند خدمات مورد نياز خود را به دست آورند (FA). در مطالعهى گوهرىنزاد و همكاران نيز بيان شده است كه سيستم مراقبت سالمندان حال حاضر ايران خدمات مـورد نيـاز سـالمندان را بـه صـورت براكنـده، غيـر

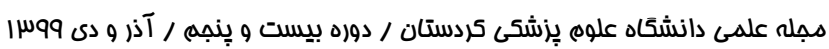


الكَوى مناسب براى سالمندان ايران برداختـه بـود در نهايـت بيشنهاد شده است كه منبع عظيم خـانواده و قـدرت فراخير

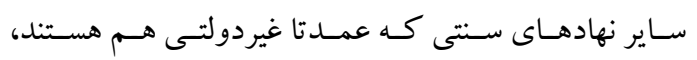

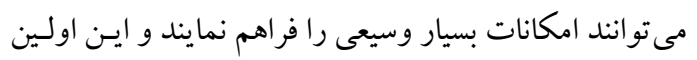
بستر است كه با بهره گيرى از آن مىتوان با كمترين هزينـه،

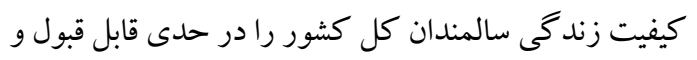
به صورت بايدار و رو به رشد در اين نسل و نسل هاى آينده

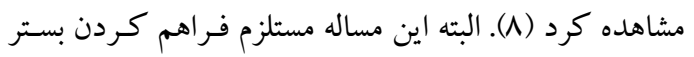

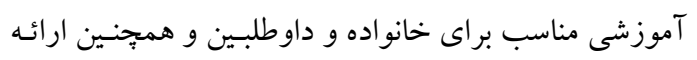

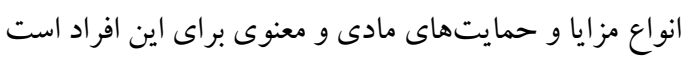

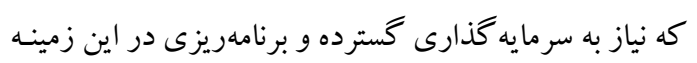
از محدوديتهاى اين مطالعه كمبـود مطالعـات و دادههـا در

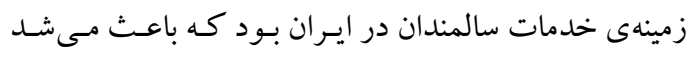

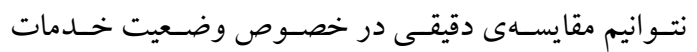

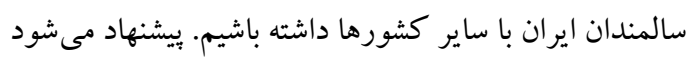
در مطالعات آتى كميت و كيفيت خدمات مراقبت سالمندان در سطوح مختلف كشور مورد بررسى قرار گيرد.

\section{نتيجه كيرى}

بر اساس نتايج حاصل از اين بثزوهش مى تـوان كفـت كـه بـا

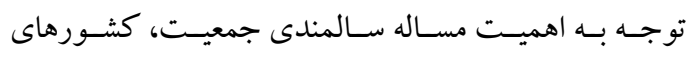
توسعه يافته اقـدامات سـازمان يافته متعـددى در زمينه ارائهـ

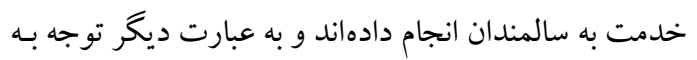

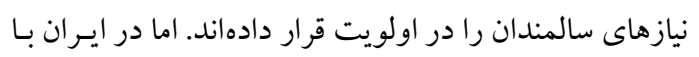
وجود اينكه در آينده نزديكك نسبت سالمندان افزايش قابـل توجهى ميابد و بـا يـك بحـران عظيم در ايـن زمينه مواجـه

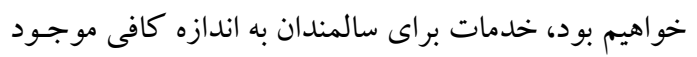

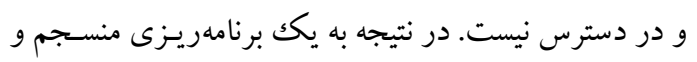

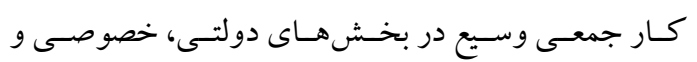

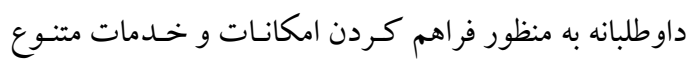

سالمندى و بررسى نحوه ارائه خـدمات مـوثر بـه ايـن گحروه

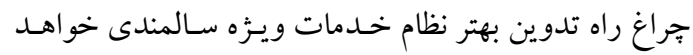

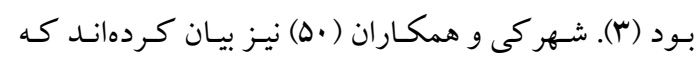

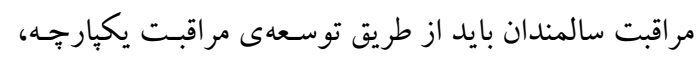
راهاندازى بيمه مناسـب، تاسيس مراكز مراقبـت سـالمندان،

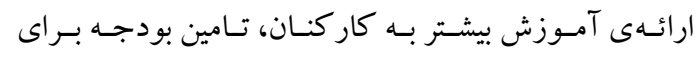
تسهيلات و تجهيزات، افزايش آكـاهى سـلامت سـالمندان و ارائهى آموزش مهارتهاى زندگى ارتقاء يابد.

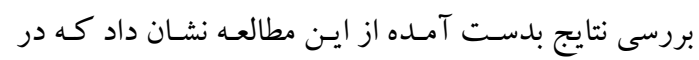

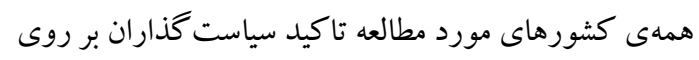

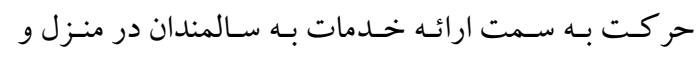
خـدمات جامعسهمحسور بـه منظـور يوشـش هرجهـ وسـيع تـر

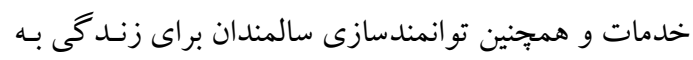

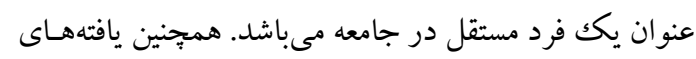

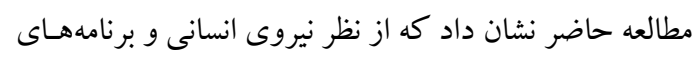

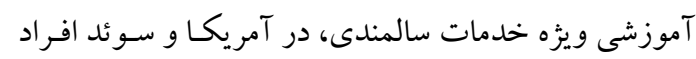
آموزش ديده در تخصص هــاى مختلـف سـالمندى بـا تعـداد

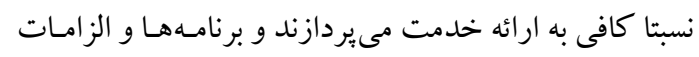

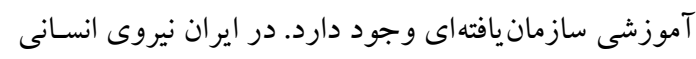

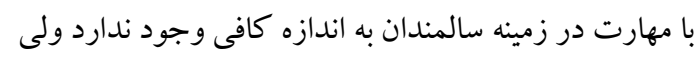
اخيرا تعدادى برنامـه آموزشى در زمينه سـالمندان در حسال راهاندازى است و اين موضوع مورد توجه قرار گرفته است.

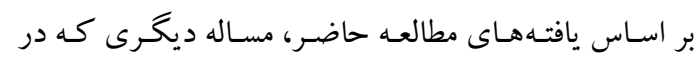

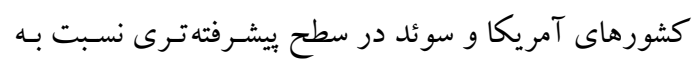

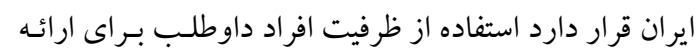

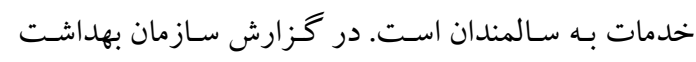
جهانى در مورد سالمندى و سـلامتى در سـال 10 ب ب توصسيه

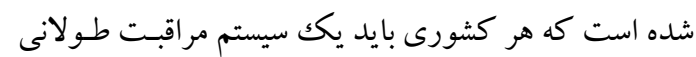

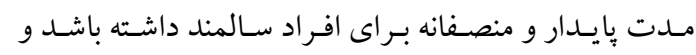

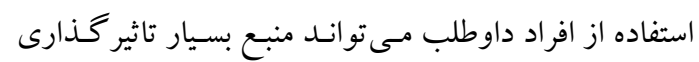

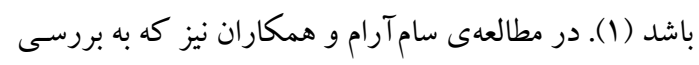
سياست هـاى اجتمـاعى سـالمندان در زايـن و سـوئد و ارائهـ 


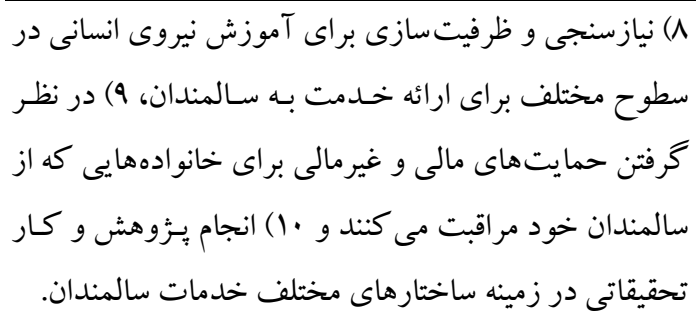

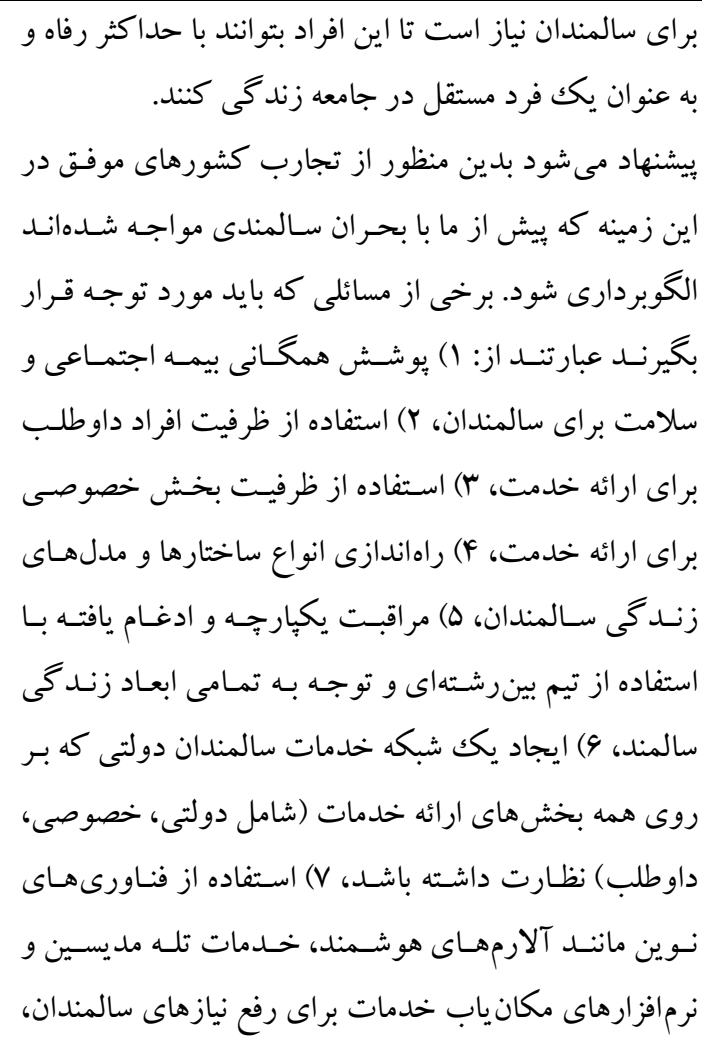

منابع

1.WHO | World report on ageing and health 2015 [Internet]. WHO. World Health Organization; 2017 [cited 2019 Feb 18]. Available from: https://www.who.int/ageing/events/world-report-2015-launch/en/

2.Beard JR, Officer A, De Carvalho IA, Sadana R, Pot AM, Michel JP, et al. The World report on ageing and health: A policy framework for healthy ageing. Lancet [Internet]. World Health Organization. Published by Elsevier Ltd/Inc/BV. All rights reserved.; 2016;387(10033):2145-54. Available from: http://dx.doi.org/10.1016/S0140-6736(15)005164

3.Dadkhah A. Elderly Services System in the United States and Japan and Providing Indicators for Developing a Strategic Plan for Elderly Services in Iran [In Persian]. Iran J Ageing. 2007;2(3):166-76.

4.Moshfegh, Mirzaee. Age transition in Iran: population age changes and social demographic policies [In Persian]. Popul Mag. 2010;17:1-22.

5.Ocampo JM. Self-rated health: Importance of use in elderly adults. Colomb MÃlcopyrightdica. scieloco; 2010;41:275-89.

6.Gutierrez-Robledo LM. Looking at the future of geriatric care in developing countries. Journals Gerontol Ser A-Biological Sci Med Sci. 2002;57(3):M162-7.

7.Sheikhi M. Sociology of Aging [In Persian]. TEHRAN: HARIR; 2010.

8.Sam Ararm E, Amin Aghaee M. Elderly Social policies in Japan and Sweden and provide a appropriate model for the elderly of Iran [In Persian]. Iran J Ageing. 2006;1(2):88-100.

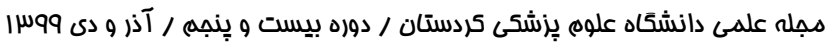


9.Shoaee F, Nejati V. Elderly Care Services in the United States with a Glance at Iran [In Persian]. Iran J Ageing. 2009;3(7):68-77.

10.Day T. About the National Aging Network [Internet]. national care planing council. 2017. Available from: https://www.longtermcarelink.net/eldercare/area_agencies_on_aging.htm 11.national council on Aging. Senior Centers [Internet]. Washington DC 20036; 2012. Available from: NATIONAL COUNCIL ON AGING\%0A1901 L Street, NW, 4th Floor $n$ Washington, DC 20036 n 202-479-1200 www.NCOA.org

12.U.S. Department of Health \& Human Services. Office of the Regional Director (ORD) [Internet]. 2018 [cited $2019 \quad$ Feb 16]. Available from: https://www.hhs.gov/about/agencies/iea/regional-offices/region-8/what-we-do/index.html 13.Fay B. Senior Health Care Options - Insurance, Medicare \&amp; Elderly Care [Internet]. [cited 2019 Feb 17]. Available from: https:/www.debt.org/medical/senior-options-costs/ 14.Centers for Medicare \& Medicaid Services. Program of All-Inclusive Care for the Elderly [Internet]. 2018 [cited 2019 Feb 14]. Available from: www.cms.gov/Medicare-MedicaidCoordination/Medicare-and-Medicaid-Coordination/Medicare-Medicaid-CoordinationOffice/PACE/PACE.html 15.national PACE Association. What Is PACE? [Internet]. 2019. Available from: https://www.npaonline.org/pace-you

16.Administration for community living. Administration on Aging [Internet]. 2019 [cited 2018 Feb 13]. Available from: https://acl.gov/about-acl/administration-aging

17.ACL. the Eldercare Locator [Internet]. 2017 [cited 2019 Feb 13]. Available from: https://eldercare.acl.gov/Public/About/Index.aspx

18.U.S. Government Accountability Office. Older Adults: Federal Strategy Needed to Help Ensure Efficient and Effective Delivery of Home and Community-Based Services and Supports. 2015;(May).

19.Moberg L, Blomqvist P, Winblad U. User choice in Swedish eldercare - conditions for informed choice and enhanced service quality. J Eur Soc Policy [Internet]. 2016;1-15. Available from: esp.sagepub.com

20.Edebalk PG. Ways of Funding and Organising Elderly Care in Sweden. In: Population Ageing-A Threat to the Welfare State? Demographic Research Monographs (A series of the Max Planck Institute for Demographic Research) [Internet]. Springer, Berlin, Heidelberg; 2010 [cited 2018 Mar 22]. p. 65-80. Available from: link. springer.com/10.1007/978-3-64212612-3 5

21.OECD/European Commission. Sweden. Highlights from A Good Life in Old Age? Monitoring and Improving Quality in Long-Term Care [Internet]. 2013 [cited 2018 Mar 22]. Available from: https://www.oecd.org/els/health-systems/Sweden-OECD-EC-Good-Time-inOld-Age.pdf

22.Davey A, Malmberg B, Sundström G. Aging in Sweden : Local Variation, Local Control. Gerontologist. 2014;54(4):525-32.

23. Gralberg A. Elderly care in Sweden Presentation Imserso October 2016 Elderly care $65+$. 2016.

24.Jönsson I, Daune-Richard A-M, Odena S, Ring M. The implementation of elder-care in France and Sweden: a macro and micro perspective. Ageing Soc Cam- Bridg Univ Press. 2011;31:1-20.

25.Johansson L, Long H, Parker MG. Informal Caregiving for Elders in Sweden: An Analysis of Current Policy Developments. J Aging Soc Policy [Internet]. 2011;23(4):335-53. Available from: http://dx.doi.org/10.1080/08959420.2011.605630 PLEASE 
عسل السادات نيارئيس زواره وسر

26.Edström A, Gustafsson M. Elderly Living in Sweden Present solutions and future trends Master of Science thesis. 2011.

27.This is the Ministry of Health and Social Affairs [Internet]. 2016. Available from: government.se

28.Taheri A, Shirani M, Zohouri M. The role of information technology in elderly's health programs: A comparison in Sweden and France [in persian]. J Hosp [Internet]. 2014; Available from: http://jhosp.tums.ac.ir/article- - _- $\Delta \Delta$ l-fa.html

29.Institutions covering elderly services [In Persian] [Internet]. Secretariat National Council of the Elderly. Available from: http://snce.ir/?page_id=13255

30.Imanzadeh A, Hamrahzdeh M. Identification of Facilitators and Deterrents of the Quality of Life in Elderly Women and Men: A Phenomenological Research. Iran J Ageing [Internet]. 2018;12(4):430-45. Available from: http://salmandj.uswr.ac.ir/article-1-1248-en.html

31.Khodaveisi M, Faal Araghi Nejad A, Omidi A, Esmaeili Vardanjani A, Tapak L. Comparing the Structural Standards of Nursing Homes in Markazi Province, Iran With International Standards. Iran J Ageing. 2018;13(3):362-71.

32.Nasiri M, Foroughan M, Rashedi V, Makarem A, Jafari Mourjan B. Compliance to Universal Design Criteria in Nursing Homes of Tehran. Iran J Ageing. 2016;11(2):340-7.

33. National elderly document of Iran [Internet]. Secretariat National Council of the Elderly of Iran; 2017. Available from: http://snce.ir/?page_id=703

34. Butler S. Direct Care Workers in Community-based Settings_2015_PPT. 2015.

35.Geriatrics healthcare Professionals. Training Requirements [Internet]. 2019. Available from: https://www.americangeriatrics.org/geriatrics-profession/training-requirements.

36. facts about sweden, elderly care [Internet]. 2013. Available from: sweden.se 37.Fukushima N, Adami J, Palme M. The Swedish Long-term Care System. ENEPRI Research Report. 2010;89. Available from: http://www.ancien-longtermcare.eu/node/27

38.Szebehely M, Trydegard G-B. Home care for older people in Sweden: a universal model in transition. Heal Soc Care Community. 2011;1-10.

39.Elderly care in Sweden [Internet]. [cited 2018 Mar 22]. Available from: https://sweden.se/society/elderly-care-in-sweden/

40.Jegermalm M. Housing and Care of the Elderly in Sweden: The Role of the Municipalities. In: Conference 3rd of September 2013 in the Hague, arranged by the European Urban Knowledge Network. 2013. p. 1-9.

41.Simonazzi A. Care regimes and national employment models. Cambridge J Econ [Internet]. 2008;33(2):211-32. Available from: academic.oup.com/cje/articlelookup/doi/10.1093/cje/ben043

42.Nilsson A, Engström M. E-assessment and an e-training program among elderly care staff lacking formal competence: results of a mixed-methods intervention study. BMC Health Serv Res. 2015;15(189):1-11.

43. National Council of the Elderly at a Glance [In Persian] [Internet]. Secretariat National Council of the Elderly. [cited 2019 Feb 15]. Available from: http://snce.ir/?page_id=9135

44.Siam S. Nursing homes. In: Elderly Issues in Iran and the World Survey [In Persian]. 2002 .

45.Parsa P, Rezapur-Shahkolai F, Araghchian M, Afshari M, Moradi A. Medical Procedure Problems From the Viewpoint of Elderly Referrals to Healthcare Centers of Hamedan: A Qualitative Study. Iran J Ageing [Internet]. 2017;12(2):146-55. Available from: http://dx.doi.org/10.21859/sija-1202146

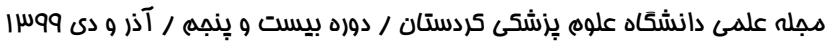


46.Safdari R, Alizadeh M, Mohamadiazar M, Sharifi F, Fakhrzadeh H. Comparative study of home care program in iran with other developed countries. Iran J Diabetes Metab (Elderly Heal Res Center, Spec Issue). 2014;13(6):439-47.

47.Darabi S, Mirzaie M, Darabi S, Babapour M. Population Aging in Iran and Rising Health Care Costs [In Persian]. Iran J Ageing. 2017;12(2):156-69.

48. Foroughan M, Nasiri M, Rashedi V, Shahbazi MR. The Impact of Rehabilitation Module of Iran Welfare Organization among Older Adults. Salmand Iran J Ageing. 2016;11(1):110 7.

49.Goharinezhad S, Maleki M, Baradaran HR, Ravaghi H. A qualitative study of the current situation of elderly care in Iran: what can we do for the future? Glob Health Action. Informa UK Limited; 2016 Dec;9(1):32156.

50.Shahraki SK, Nayeri ND, Pouraboli B, Abazari F. Challenges in caring for the elderly in Iran: A systematic review. Ethiop Med J. 2018;56(2):189-96.

51.United States Population 2019 (Demographics, Maps, Graphs) [Internet]. 2018 [cited 2019 Feb 18]. Available from: http://worldpopulationreview.com/countries/united-statespopulation/

52.World Population Ageing 2017- Highlights (ST/ESA/SER.A/397). United Nations, Department of Economic and Social Affairs, Population Division; 2017.

53.Life expectancy at birth [Internet]. OECD Health Statistics. 2017 [cited 2019 Feb 18]. Available from: https://data.oecd.org/healthstat/life-expectancy-at-birth.htm

54.Largest population increase expected among the elderly [Internet]. Statistical news from Statistics Sweden. 2018. Available from: http://www.scb.se/en/finding-statistics/statistics-bysubject-area/population/population-projections/population-projections/pong/statisticalnews/the-future-population-of-sweden-2018-2070/ 